\author{
Pavel Bednár̆ \\ PhD, Head of the Department of Regional Development, Public Sector Administration and Law \\ e-mail: bednar@utb.cz,ORCID ID: https://orcid.org/0000-0003-1250-5762 \\ Lukáš Danko \\ PhD, Assistant Professor of the Department of Regional Development, Public Sector Administration and Law \\ e-mail: danko@utb.cz,ORCID ID: https://orcid.org/0000-0001-7404-8857 \\ Tomas Bata University in Zlín, Faculty of Management and Economics, Mostni 5139, Zlín, 76001, Czech Republic
}

\title{
MAPPING SPATIO-TEMPORAL PATTERNS OF CREATIVE INDUSTRIES DEVELOPMENT IN THE CZECH REPUBLIC
}

Creative industries characterized by subsectors of architecture, design, and advertising represent an important segment in implementation of post-Fordist economy principles. Hence, the governments and scholars are devoted to quantitative mapping of creative industries. The results of this mapping provide insight into number, structure and spatial distribution in a given area for subsequent identification of smart specialization of cities and regions. Furthermore, they serve as a basis for strategic planning of regional innovation systems. Finally yet importantly, this mapping is the basis for following qualitative mapping through research methods such as focus groups and the Delphi method among key actors of the particular creative ecosystem.

Unique feature of this paper is mainly in the methodology, which is detached from the traditional static view on the quantitative mapping of creative industries dealing with cross-sectional data solely. Therefore, this paper develops their use to spatial mapping of creative industries by the dynamic component concerning new approaches to Exploratory Spatial Data Analysis. This component is based on unbalanced panel dataset by using the differential local Moran's I.

The results indicate a dynamic development of design and advertising enterprises at the municipal level in the Czech Republic, with options for internationalization of market, uniqueness of products and continual digitalization. On the contrary, subsector of architecture was identified as stagnant in terms of development, in relation to demand for these services that are affected by limited national real estate market, continual concentration of developers. Furthermore, the results revealed links between their spatial diffusion with process of residential suburbanization and strengthening of existing centres through the agglomeration and urbanization economies. Thus, those specifics underline a call for appropriate smart specialization policies along with policies concerning creative class retention in regional centres and rural areas.

Keywords: cluster, creative industries, Czech Republic, differential LISA, spatial distribution. \section{КРЕАТИВНОӤ ІНДУСТРІЇ В ЧЕСЬКІЙ РЕСПУБЛЦІ \\ ПавеЛ Беднар, Лукаш Данко. КАРТОГРАФУВАННЯ ПРОСТОРОВО-ЧАСОВИХ МОДЕЛЕЙ РОЗВИТКУ}

Креативні галузі, що характеризуються підсекторами архітектури, дизайну і реклами, являють собою важливий сегмент в реалізації принципів пост-фордистської економіки. Тому для органів влади і науковців актуальними є питання кількісного картографування креативної індустрії. Результати цього відображення дають уявлення про кількість, структуру і просторовий розподіл у даній сфері для подальшої ідентифікації смарт-спеціалізації міст і регіонів. Крім того, вони слугують основою для стратегічного планування регіональних інноваційних систем. Нарешті, важливо те, що це відображення $\epsilon$ основою для подальшого якісного відображення за допомогою таких методів дослідження як фокус-групи і метод Дельфі.

Унікальною особливістю цієї статті є головним чином методологія, яка відокремлена від традиційного статичного уявлення про кількісне картографування креативної індустрії, що має справу лише з даними поперечного перерізу. Таким чином, ця стаття розвиває їх використання для просторового картографування креативної індустрії за допомогою динамічного компонента, що стосується нових підходів до дослідницького аналізу просторових даних. Цей компонент заснований на незбалансованому наборі даних панелі з використанням диференціального локального Морана I.

Результати вказують на динамічний розвиток дизайнерських та рекламних підприємств на муніципальному рівні у Чеській Республіці з варіантами інтернаціоналізації ринку, унікальності продуктів і безперервної цифровізації. Натомість підсектор архітектури був визначений як застійний з точки зору розвитку щодо попиту на ці послуги, на який впливає обмежений національний ринок нерухомості, постійна концентрація забудовників. Крім того, результати виявили зв'язок між їх просторовим поширенням з процесом приміської житлової забудови і зміцненням існуючих центрів через економіку агломерації і урбанізації. Таким чином, ці особливості підкреслюють заклик до належної політики смарт-спеціалізації нарівні 3 політикою, що стосується збереження креативного класу в регіональних центрах і сільській місцевості.

Ключові слова: кластер, креативна індустрія, Чехія, диференціальна LISA, просторовий розподіл.

Павел Беднар, Лукаш Данко. КАРТОГРАФИРОВАНИЕ ПРОСТРАНСТВЕННО-ВРЕМЕННЫХ МОДЕЛЕЙ РАЗВИТИЯ КРЕАТИВНОЙ ИНДУСТРИИ В ЧЕШСКОЙ РЕСПУБЛИКЕ

Креативные отрасли, характеризуемые подсекторами архитектуры, дизайна и рекламы, представляют собой важный сегмент в реализации принципов пост-фордистской экономики. Следовательно, для органов власти и ученых актуальными являются вопросы количественного картографирования креативной индустрии. Результаты этого отображения дают представление о количестве, структуре и пространственном распределении в данной сфере для последующей идентификации смарт-специализации городов и регионов. Кроме того, они служат основой для стратегического планирования региональных инновационных систем. Наконец, важно то, что это отображение является основой для последующего качественного отображения с помощью таких методов исследования как фокус-группы и метод Дельфи.

(C) Bednáŕ P., Danko L., 2018 
Уникальной особенностью этой статьи является главным образом методология, которая отделена от традиционного статического представления о количественном картографирования креативной индустрии, имеющего дело только с данными поперечного сечения. Таким образом, эта статья развивает их использование для пространственного картографирования креативной индустрии с помощью динамического компонента, касающегося новых подходов к исследовательскому анализу пространственных данных. Этот компонент основан на несбалансированном наборе данных панели с использованием дифференциального локального Морана I.

Результаты указывают на динамичное развитие дизайнерских и рекламных предприятий на муниципальном уровне в Чешской Республике с вариантами интернационализации рынка, уникальности продуктов и непрерывной цифровизации. Напротив, подсектор архитектуры был определен как застойный с точки зрения развития, в отношении спроса на эти услуги, на который влияет ограниченный национальный рынок недвижимости, постоянная концентрация застройщиков. Кроме того, результаты выявили связь между их пространственным распространением с процессом пригородной жилой застройки и укреплением существующих центров через экономику агломерации и урбанизации. Таким образом, эти особенности подчеркивают призыв к надлежащей политике смарт-специализации наряду с политикой, касающейся сохранения креативного класса в региональных центрах и сельской местности.

Ключевые слова: кластер, креативная индустрия, Чехия, дифференциальная LISA, пространственное распределение.

1. Introduction. Mapping the Creative industries (CI) is an essential element for understanding their spatial distribution. Furthermore, it provides an insight into their development in relation to implementation of diverse public policies. These policies are ranging from cultural, industrial, innovation to cluster strategies. Thus, many countries of the EU prepared mapping documents at national level, for example DCMS in the United Kingdom [1], and Bednář et al. [2] in the Czech Republic. Mapping documents were based on the positive impact of the CI on economies in developed countries. Hence, their primary objective is to support the competitiveness of commercially-oriented creative industries architecture, design, and advertising at the national level.

The competitiveness is oriented at outputs, which are considered unique and innovative with higher added value. On the other hand, these processes lead to building the brand of respective country, region or city. Competitive outputs of the CI become part of the cultural heritage and hence national identity in the long run.

The growth of the CI in developed countries was given by continuous spatial division of labour [3], where many industries with low added value or standardized mass production respectively were transferred to emerging countries in South-eastern and East Asia. Furthermore, developed countries maintained research and development including design with marketing strategies by transnational corporations (TNC). However, these countries were affected by bankruptcies of traditional industries and inner cities with industrial areas based on the Fordism that changed into brownfields. Consequently, there was a rise of production capacities including research and development in industrialized countries such as South Korea, Taiwan and China. In response, the need for change of the paradigm of economic growth in developed countries was addressed by post-Fordist systems of production based in economies of scope aforementioned information and communication technologies. These events along with increased access for tertiary education led in to the rise of the Creative Class [4] that was essential for innovative approaches to solve problems and filly meet the needs of post-Fordist systems in developed countries as they were seeking for new sources of competitiveness comparing to industrialized countries.

Former socialist countries of Central and Eastern Europe (CEE) were object of time-lag in favour of the CI compared to developed countries. This was the case mainly due to the low-road development in the 1990s and first decade of $21^{\text {st }}$ century. This strategy was taken mainly because of the need to transform these economies from centrally planned to market oriented with the goal to employ as many people as possible from declining industries. However, the development of business and consumer services was not able to absorb changes in the labour market. The main competitive advantage of these countries was and even now is the lower cost of labour compared to developed countries. Nevertheless, the CEE countries realized low-road development was unsustainable, mainly due to their accession to the EU, the use of structural funds, continuous digitalization, and competitive standardized production of South-east and East Asia countries. Thus, the activities towards support for commercially oriented CI with product, process and marketing innovation were initiated. Research and development was also initiated under the Creative Europe programme in 2010 in relation to basic and applied research for mapping the CI. In this case, the quantitative mapping was available with the use thematic cartography and spatial statistics or modelling in order to identify spatial patterns or features that determine their spatial distribution $[5,6,7,8,9]$. However, these papers primarily deal with the spatial dimension of the CI distribution and the lack of time dimension of their development.

Therefore, the aim of this paper is to introduce spatio-temporal changes in the volume and distribution of the CI in the Czech Republic, with focus on architecture, design and advertising. These branches represent commercially oriented activities associated with agglomeration and urbanization benefits. The aforementioned temporal changes will cover the state of development among mentioned branches in 2004 and 2018. These unites were selected purposely due to the accession of the Czech Republic to the EU (2004) and current state (2004). The advantage of this comparison is mainly the same period of fourteen years from January 1990 to April 2004, and second case between May 2004 and June 2018. Thus, this paper provides an overview on spatio-temporal differences in development of selected branches in relation to systematic changes and spontaneous global trends in development of the IT and telecommunication. At least but not last, the aim of this paper is to specify the processing of an unbalanced panel dataset using Exploratory Spatial Data Analysis. This allows assessing the dynamics of the CI and their spatial distribution in Visegrad countries, i.e. the Czech Republic, 
Hungary, Poland, and Slovakia. Visegrad countries share similar conditions for the CI development due to their shared experience with centrally planned economy and the dominant position of the capital in the economic, cultural and social scopes. These scopes are prerequisite for the development of creative milieu.

2. Underlying principles of the cultural and creative industries. Recent trends in economic development reflect on the need of growth and advancement of knowledge intensive business services (KIBS). These services can address and deal with the slump of the overall production in certain economies. Furthermore, the service sector is also challenged in order to utilize resources within smart governance and sustainable development. This in fact puts a pressure on economic planning and development trajectories that currently rely on innovative activities and increasing competitiveness. Thus, public policies are more concerned with the CI as a source for innovation activities. The CCI are those industries, which use culture as an input and have a cultural dimension, although their outputs are mainly functional. They include architecture and design, which integrate creative elements into wider processes, as well as subsectors such as graphic, fashion design or advertising [10]. Furthermore, The CI are considered advanced services and due to urbanization economies they often overlap in particular areas and create hubs and networks [11]. In addition, [12] argue there are synergies concerning different branches of creative industries with their colocation as creative hubs. Furthermore, they emphasise synergies between creative industries and other sectors such as High-Tech and KIBS. Gordon and McCann [13] suggest colocation is often associated with social networks and ties rather than simple agglomeration for cost reduction.

Consequently, organisations benefit when they are located nearby and they generate attractive milieu spillovers for further attraction of creative individuals [14]. These links underline the importance of creative economy and its position from periphery of public policies and governance towards the planning and governance. This movement is also encouraged by an innovative notion of the CI, as they maintain higher pace regarding innovativeness than some high-tech sectors [3]. Furthermore, the CI also prove their influence on economic development from macroeconomic perspective, as they globally contribute to revenues (cca. US\$709b) and employment (7,7m. employees). On the other hand, the CI and its importance overlap economic and urban development. O'Connor [15] identified the role of the CI towards the societal change as a results of links between economy, culture, urban planning, and competitiveness. Thus, the change led to the progress of the creative class when individuals utilize creativity as a source for added value [16] [17]. As Kloudová [18] underlines creativity initiates the ability to come up with original ideas and solutions. Professionals, artists, scientists represent the creative class specialized in design, architecture, arts, music, education, and entertainment. Additionally, the process of creating added value is greater than before due to information technologies and digitalization. According to Vinodrai [19] it allows production to be more flexible as the labour force moves from place to place based on their beliefs of aesthetics, atmosphere, and emotion. Moreover, another specific feature of the creative class in the CI is its way of unique outcomes, which are often results of project-oriented production. Communities, where the creative class is concentrated are more competitive and more inclined to adopt advanced technologies [20].

Rationale for creative cities. The CI and their originality provide basis for one of the pillars for urban competitiveness, as the CI tend to encourage productivity, regeneration of deprived areas and promoting attractiveness of areas in order to improve quality of life [21]. Thus, there are often secondary matters that highlight the effect of the CI advancement. These are mainly associated with process of de-industrialization and regeneration on the urban level in order to attain creative cities. Creative cities became a case in the $21^{\text {st }}$ century with refined urban planning aimed for improving a quality of life. Thus, there are various aspects of creative cities that brand them creative. Mostly, there are cultural, intellectual, technological and organisational characteristics that are designed to create favourable atmosphere for the CI [22] However, current debates among scholars regarding the creative cities is not limited solely to attraction of the CI per se, but rather its' retention in particular areas. Factors influencing the retention are associated with pleasant neighbourhood characteristics, access to local cultural amenities, and lifestyle [23].

On the contrary, factors influencing the retention of the $\mathrm{CI}$ in small and rural places are community sense, outdoor amenities a, and time with family [24]. However, creative cities are not solely relevant due to the creative class and communities, because they also reflect on advantages such as customer-supplier chain and access to qualified labour [15]. Thus, cities nowadays invest in cultural and creative amenities in order to regenerate and support economic development within urban planning and design. This movement generates new ways of competitiveness between cities regarding a quality of life. Nevertheless, even creative cities might not be taken as a whole, but rather as districts and milieus where creativity and people concentrates. Creative districts and milieus are specific areas, where individuals gather to communities and interact with each other, mainly with various form of communication [25]. Creatives, social environment and mutual interaction encourage sharing new ideas and solutions. Moreover, this interaction is often informal with the aim to achieve socio-economic development it these areas. The creative milieu in this regard symbolises mutual trust between individuals for knowledge sharing. These activities in communities often expend over creative milieu in terms of spatial perspective. Thus, the concentration of creative communities with economic and leisure activities leads to an embeddedness in creative districts in urban areas [26].

Urbanized areas with favourable conditions for creatives regarding work-life balance attract potential specialized labour force with related and emerging industries. As Krätke [27] argues creative districts reflect on specific elements such as cultural amenities, non-profit organizations, freelancers, and volunteers that create attractive conditions for work, leisure time and tourism. Furthermore, creative districts can be used as a tool for 
economic regeneration of areas, as they also represent an idea of smart specialization on urban level. Support and development of creative districts and urban areas is also one of the "soft" factors for localization of economic activities and competitiveness of cities. Alberti and Giusti [28] believe creative districts can be perceived as one of drivers for gaining competitive advantage, mainly due to the access to knowledge, skills, abilities and practice in technology use, communication and production. However, these conditions differ due to various ways of socio-economic development and governance on urban level. Uneven development is affected by different perception of creative economy as a driver for regional development. This outline is evident among countries that are currently at the initial stage of support for creative industries due to low-road economic development strategies [29]. These principles were previously implemented within planning in Central and East Europe (CEE). Thus, they now face new challenges regarding support for CI and development of city-regions regarding urban transition. Advancement of the CI might be thought provoking mainly in post-communist cities that go through institutional transformation, the change of social practices and urban space for instance Prague [30]. Furthermore, it the relevance of the CI for urban development is derived from new socio-spatial processes by movement of young populations to less attractive districts [31]. Hence, the aim of this paper is to examine spatial patterns of the CI among municipalities in the Czech Republic.

3. Data and Methods. The following three branches: architecture, design, and advertisement, were selected to represent the spatio-temporal patters of the CI development in the Czech Republic. These branches are primarily focused on commercial activities and they are considerably associated with agglomeration and urbanization benefits [7]. This selection respects the classification of the CI for their mapping in the Czech Republic according to Bednár et al. [2,30p]. Subsequently, the data for CZ-NACE were surveyed as following: (a) 71.11 Architectural activities; (b) 74.10 Specialized design; (c) 73.11 Activities of advertising agencies. The data was based on commercial Bisnode database that collects data from the Register of Economic Entities of the Czech Statistical Office and the Ministry of Finance of the Czech Republic at national level. Collected data refers to the registered offices of individual enterprises as the database does not offer list of their affiliates. The selection of enterprises into the final database respects the procedure in Bednár et al [2, 63-64p]. Thus, the database excluded enterprises where neither the turnover nor number of employees were reported. These enterprises were considered inactive, as they do not engage in economic activities in last two years. Enterprises in liquidation were also excluded. The assignment of individual enterprises to the selected CZ NACE was based on their predominant activity, which is major for turnover. Consequently, individual companies were aggregated at the municipal level as the basis for analysis. The municipal level was selected in order to limit the influence of modifiable areal unit problem in spatial analysis as opposed variability of the territorial size of aggregated units such as the NUTS 3 level, i.e. regions of the Czech Republic.
The descriptive statistics was employed to provide overview of the development of selected subsectors of the CI. Thus, frequency tables with absolute, relative frequencies and box plots showing the development of these subsectors over time were selected to provide the overview. This analysis was focused on median position and the location and length of the box and whisker plots quartiles.

Consequently, the Differential Moran's I was selected to analyse changes in the spatio-temporal distribution of selected sub-sectors of the CI in the Czech Republic at municipal level between 2004 and 2018.

First goal was to determine the selection of criteria for the definition of a spatial weights matrix, which should respect the geographical characteristics of the studied area. The matrix was established in accordance to Blažek [32]. Thus, the second order Queen contiguity matrix including lower orders was selected as the most suitable for this paper. The reason for this selection was mainly due to the structure of suburban zones in the Czech Republic, especially in Prague Metropolitan Area with highest intensity of residential suburbanization [33].

As Grekousis [34] noted, the differential global or local Moran's I is used to identify whether changes in the overtime are spatially clustered. Thus, it measures the spatial patterns of the changes of the same attribute between two different times [35]. The simulation process within the differential local Moran's I is done by using conditional random permutations (ibid.). Thus, to implement this for out subsectors $10^{5}$ permutations were applied. Hence, this is considered as source of assessment whether spatio-temporal autocorrelation exists. Based on Koschinsky [36] the interpretation of results of the global or local differential Moran's I is that it tests to find out if a variable's change over time in a given location is statistically related to that of its neighbours. Thus, it addresses the question whether there are clusters of changes in particular creative industries subsector 20042018. A high-high cluster would be one with aboveaverage 2004-2018 changes in an area and its neighbours and Low-low would be below-average changes vice versa, i.e. there is a positive spatial autocorrelation. Lowhigh cluster would be small changes in the core vs. high changes in the neighbours and high-low vice versa, i.e. there is a negative spatial autocorrelation.

4. Mapping creative industries in the Czech Republic. The first part of spatio-temporal analysis of selected subsectors of the CI at municipal level provides an overview of their structure. Moreover, in terms of time the analysis dates back to April 2004 before accession of the Czech Republic to the EU and current situation that reflects the development towards June 2018. Table 1 shows the total number of 30,882 enterprises in selected subsectors of the CI in June 2018, of which 13,718 had been established before accession to the EU (44.4\%). Thus, most of these enterprises were established between 2004 and 2018. Similar situation can be observed in case of design, where $38.2 \%$ of currently active enterprises had been established before 2004. However, advertising had the most significant relative increase of $210.9 \%$ from 2004 to 2018 , where $32.2 \%$ of currently active enterprises had been established before 2004. The opposite development can be observed in case of architecture, 
where $62.0 \%$ of enterprises had been active prior the accession to the EU. Furthermore, there was a structural change in subsectors of the CI. Architecture had a dominant position before accession to the EU with $54.4 \%$ followed by advertising with $36.6 \%$ and design with $9 \%$ respectively. In contrast, the current structure is different due to significant increase of advertising activities with $50.5 \%$ followed by architecture with $39 \%$, and design with $10.5 \%$ respectively.

Enterprises in the subsectors of creative industries in the Czech Republic $(2004,2018)$

\begin{tabular}{|l|c|c|c|c|}
\hline & Prior to joining the EU & After joining the EU & Percentage change & Total \\
\hline Architecture & 7,458 & 4,578 & 61.4 & 12,036 \\
\hline Design & 1,241 & 1,999 & 161.1 & 3,240 \\
\hline Advertisement & 5,019 & 10,587 & 210.9 & 15,606 \\
\hline Total & 13,718 & 17,164 & 125.1 & 30,882 \\
\hline
\end{tabular}

Source: Authors' results based on Bisnode 2018

The second part of the analysis presents the overview on development of selected subsectors in time. The beginning of the analysed period dates back to the January $1^{\text {st }} 1990$, when the Velvet Revolution began on November $17^{\text {th }} 1989$. Subsequently, this process endorsed the development of private enterprises. Few enterprises, which established prior to this date, were moved here to limit outliers and to misrepresent the CI development. The number of defunct enterprises can be considered insignificant in terms of overall development and structure as it does not occur in these sectors compared to culture and cultural industries (radio and film). Graph 1 illustrates that enterprises in subsector of architecture are characterized by the median value of establishment around 1998. Thus, half of all architectural enterprises were established eight years after the Velvet Revolution that reflects their stagnant development and the market saturation. Quite the opposite, design and advertising are characterized by the median value of establishment around 2010 that means half of these enterprises were established after 2010. In fact, a quarter of them were established in last three years. This process indicates the positive impact of the current peak of conjuncture within the economic cycles in the Czech Republic. We can argue they are dynamically developing sectors in relation to demand for innovation, flexible production, and orientation to the customers' needs in the post-Fordist economy.

Graph 1: Box plot of development of enterprises in the subsectors of creative industries in the Czech Republic (1990-2018)

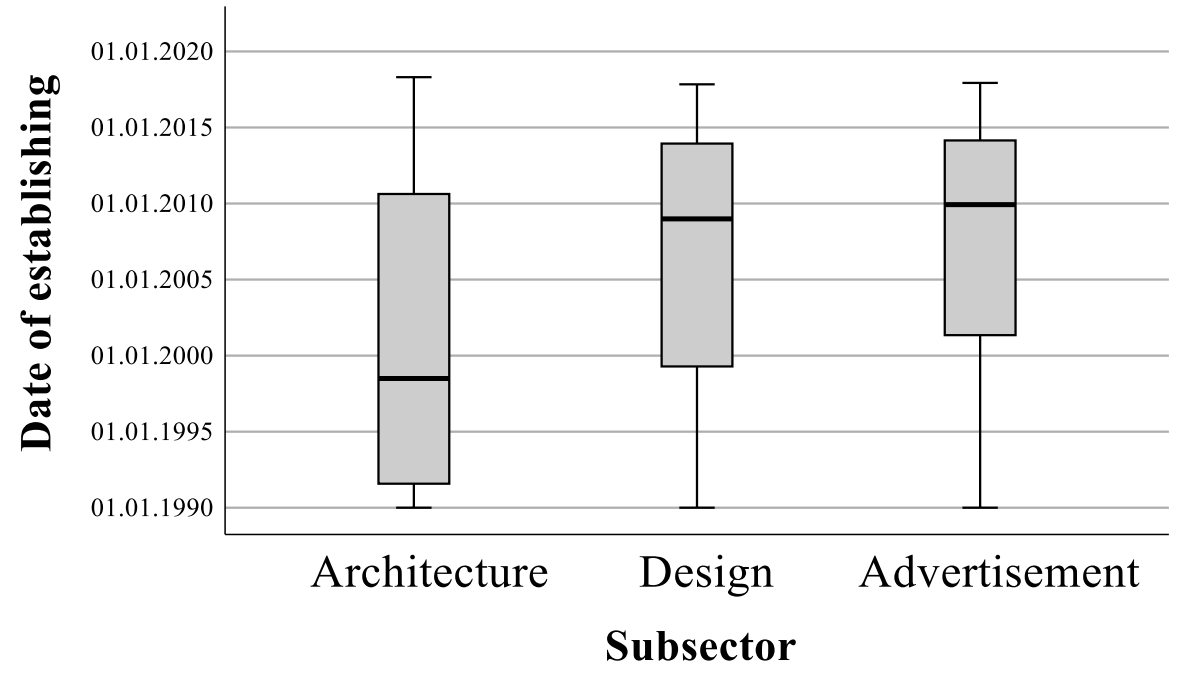

Source: Authors' results based on Bisnode 2018

Mapping spatio-temporal patters on the $\mathrm{CI}$ at municipal level in the Czech Republic between 2004 and 2018 is presented by individual subsectors. The cluster maps below illustrate both positive and negative clusters of spatial autocorrelation. Hot spots with above-average values of changes in an area and its neighbours between 2004-2018 and cold spots with under-average changes in an area and its neighbours between 2004-2018 were identified in the first place. Consequently, we identified the spatial outliers that characterize places with small changes in the core versus high changes in the neighbours and vice versa.

Figure 1 demonstrates hot spots in the South Moravian Regions, especially around Brno as the second largest city in the Czech Republic with population of 400,000. The presence of the Faculty of Architecture and the Faculty of Civil Engineering might be the reason for hot spot. Both these faculties form a basis of creative milieu and provide an education. Furthermore, an ongoing residential suburbanization due to the presence of 
major TNC in ICT and precision engineering might be another reason, which is also evident in other suburban areas in capital cities of NUTS3 regions. Last but not least, this subsector might be attributed to the presence of the most important ethnographic regions of the Czech Republic, namely Moravian Slovakia with specific building structure. A similar description can be seen in Moravian Vallachia ethnographic region in the east part of the Czech Republic, around the regional capital Zlín. The city is one of the most important centres of functionalist architecture and an implementation of urban design concept garden city on a global scale. Both Zlín and Brno are characterized by the occurrence of pathdependency in terms of previous influence of national project and construction offices under socialism. There are high-low spatial outliers near regional capitals around the Czech Republic, including Prague. These outliers are related to the increase in the intensity of residential suburbanization after 2004 [33]. Smaller hot spots were identified in suburban zones of the two districts capitals, i.e. Pelhřimov and Žd'ár nad Sázavou in the South Bohemian Region and Vysočina Region respectively in relation to local folk architecture and increasing demand for individual family housing.

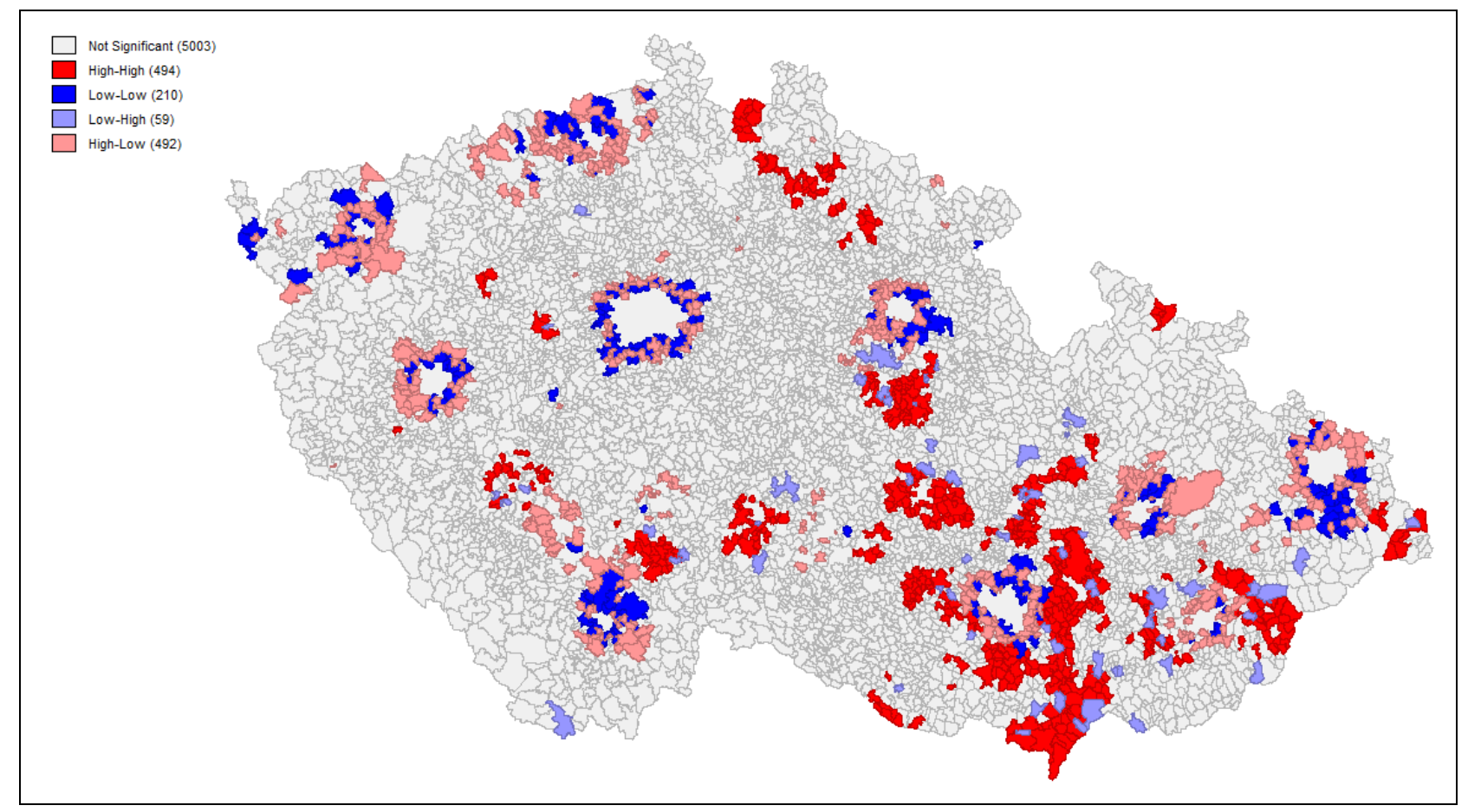

Fig. 1. Differential Local Moran's I cluster map for architecture enterprises in municipalities in the Czech Republic (2018)

Source: Authors' results based on Bisnode 2018

Mapping spatio-temporal patterns of design in the Czech Republic between 2004-2018 clearly indicates the concentration of this subsector in several centres in Prague, Pilsen, Carlsbad, Hradec Králové, Brno, Zlín, and Ostrava (see Figure 2). On the contrary, cold spots were identified on the internal periphery in the eastern part of the Czech Republic, Moravia respectively. In case of Carlsbad (hot spot) and Hradec Králové (high-low spatial outlier) there is the path-dependency in the production of porcelain and glass (Carlsbad) and production of musical instruments (Hradec Králové). Other cases are associated to the presence of Art faculties as places of knowledge and local buzz. In this respect, hot spots were identified in Brno, Ostrava and Pilsen (high-low spatial outlier) as cities with the most important centres of machinery and transport engineering in the Czech Republic that use design for their development.

A slightly different outlook can be observed in Fig- ure 3 , in case of mapping spatio-temporal patters in advertising in the Czech Republic between 2004-2018. Hot spots are significant in Prague, Ostrava, České Budějovice, and around the regional capitals such as Pilsen, Ústí nad Labem, Brno, Olomouc, and Zlín. Prague has dominant role in this respect. This might be due to the headquarters of national corporations and TNC in the Czech Republic that are the most important customers for advertising of nationwide coverage. Prague is also characterized by intense local buzz and knowledge spill over processes linked to the benefits of urbanization economies. On the contrary, hot spots in Ostrave and České Budějovice might be due to their distance from Prague and thus the opportunity to compete in prices with advertising enterprises from Prague. Ostrava has an opportunity to operate on the Polish market with good transport distance of $80 \mathrm{~km}$ to Upper Silesian metropolitan area with population of 5.3 million. 


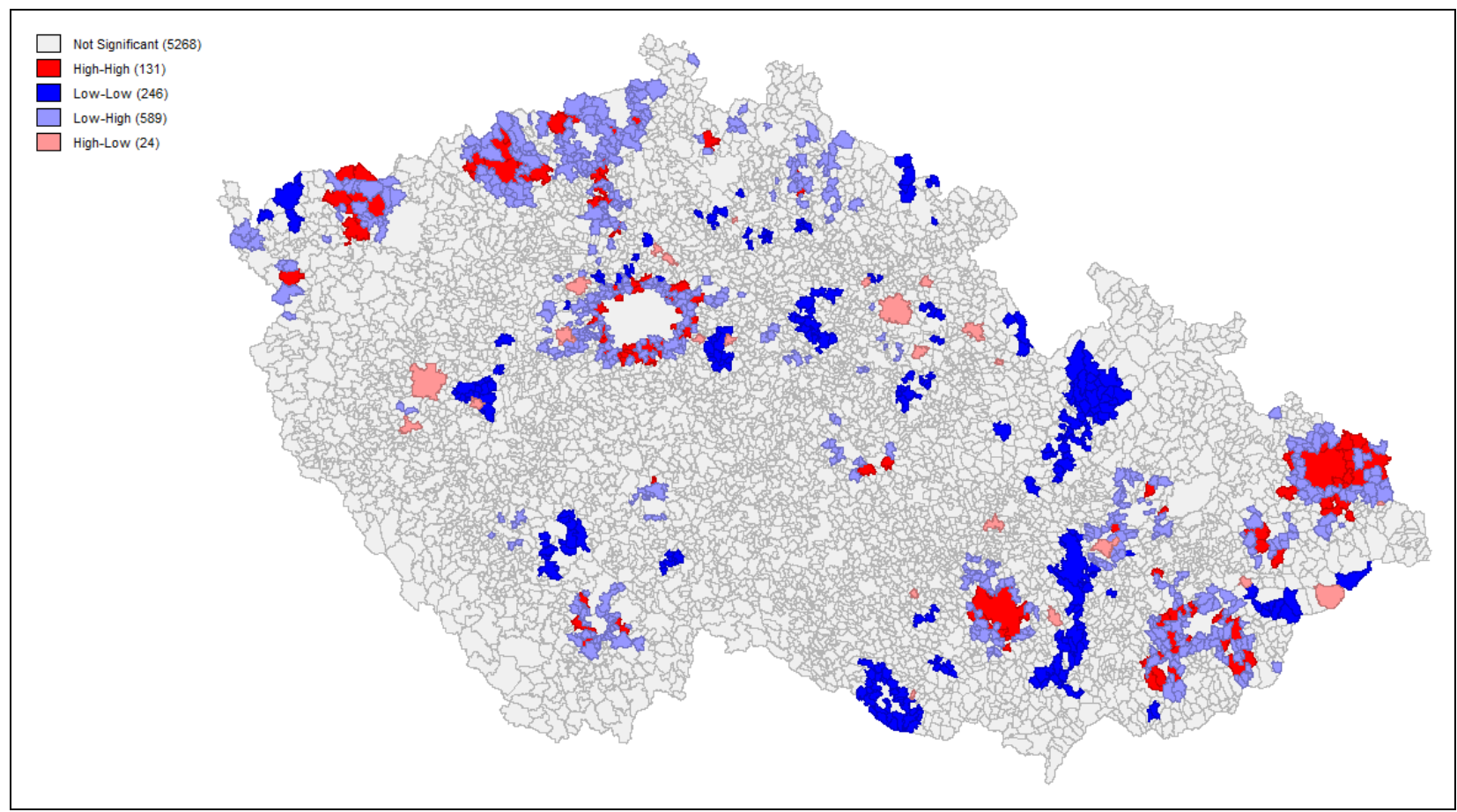

Fig. 2. Differential Local Moran's I cluster map for design enterprises in municipalities in the Czech Republic (2018)

Source: Authors' results based on Bisnode 2018

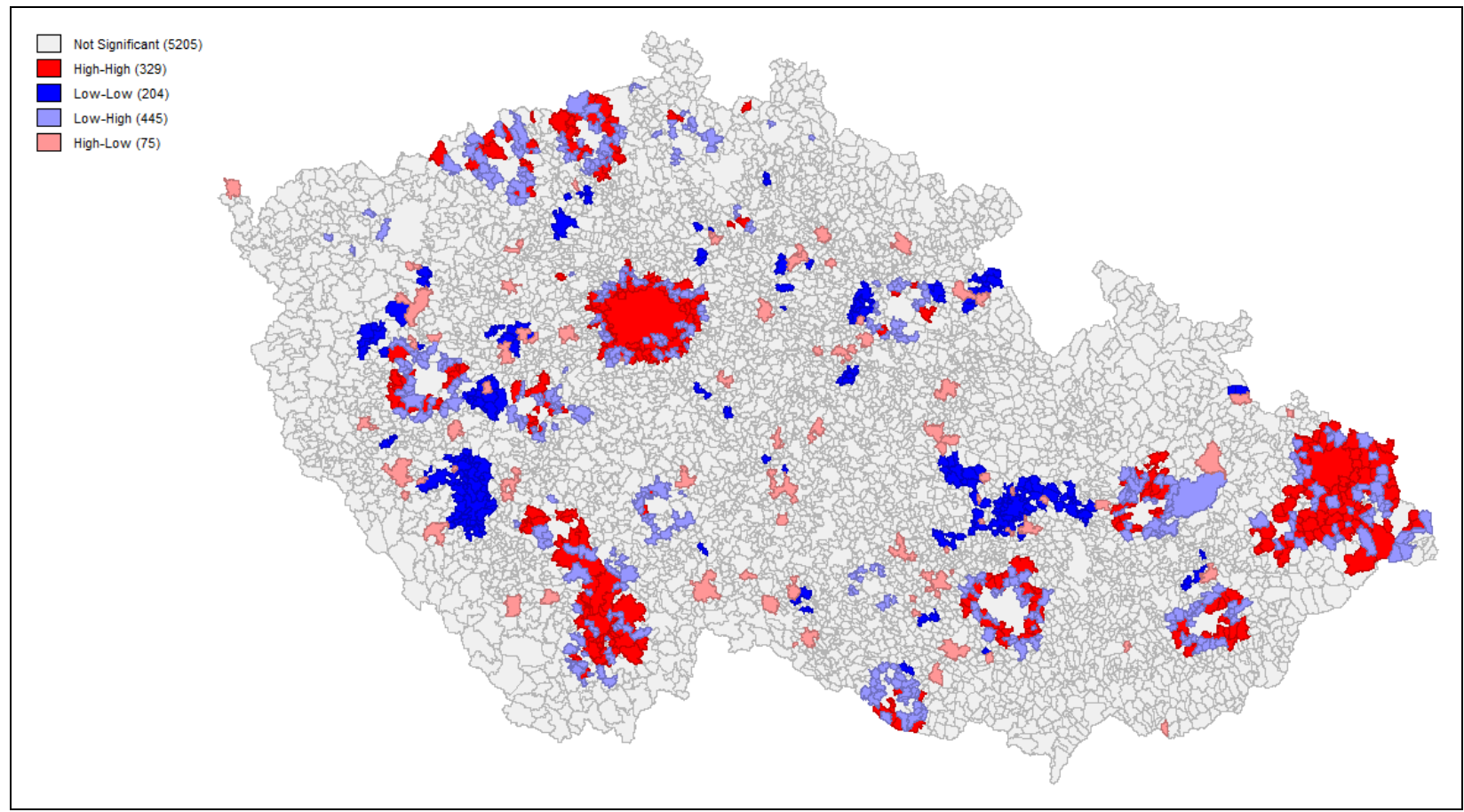

Fig. 3. Differential Local Moran's I cluster map for advertisement enterprises in municipalities in the Czech Republic (2018)

Source: Authors' results based on Bisnode 2018

5. Conclusion. The results indicate a dynamic development of design and advertising enterprises at municipal level in the Czech Republic between 2004 and 2018. This corresponds to their potential to be a part of regional innovation systems, including their significant role in the application of post-Fordist economy princi- ples. In contrast, subsector of architecture is more closed compared to previously mentioned subsectors. Even though, architecture is unique in its outcomes it has a limited overlap in other sectors. The strengthening of regional centres was revealed from spatial point of view. Regional centres including Prague, might be considered 
creative cities as reflect concentration of the creative class.

They are also characterized by appropriate knowledge base and the benefits of agglomeration and urbanization economies in relation to knowledge spillover and local buzz. The spatial diffusion (headquarters) of these subsectors to suburban areas of regional centres including and process of residential suburbanization are essential findings of the analysis. Strengthening the posi- tion of Ostrava as a centre for creative industries is also a positive factor for economic revitalization of this traditionally industrial city in relation to many cluster organizations. Future research should be focused on identification or confirmation of factors that influenced spatiotemporal patters identified in this paper. Furthermore, whether they are related to accession to the EU and phase of the economic cycle.

1. Creative Industries Mapping Document DCMS 1998

2. Žáková, E., Bednár̆, P., a kol. (2015). Mapování kulturních a kreativních průmyslů v ČR, Praha.

3. Saunders, P. (1985). Massey Doreen, Spatial Divisions of Labour. Journal of Public Policy, 5(1), 128-129.

4. Florida, R. (2014). The creative class and economic development. Economic development quarterly, 28(3), 196205.

5. Kovács, Z., Tamás, E., \& Szabó, B. (2011). Geographical aspects of creative economy in Hungary. Space and Society, 25(1), 42-62.

6. Środa-Murawska, S., Szymańska, D. (2013). The concentration of the creative sector firms as a potential basis for the formation of creative clusters in Poland. Bulletin of Geography. Socio-economic Series, 20(20), 85-93.

7. Slach, O., Koutský, J., Novotný, J., Ženka, J. (2013). Creative industries in the Czech Republic: a spatial perspective. Economics and Management, 4, 14-29.

8. Rehák, Š., Chovanec, M. (2012). Exploring spatial patterns of creative industries with firm level micro geographic data. Region Direct, 2, 10-35.

9. Nurković, R. (2015). Contemporary development of creative industries in Bosnia and Herzegovina. Quaestiones Geographicae, 34(2), 45-51.

10. European Commission. (2010) Unlocking the Potential of Cultural and Creative Industries, Brussels.

11. Boix, R., Hervás - Oliver, J. L., De Miguel-Molina, B. (2015). Micro-geographies of creative industries clusters in Europe: From hot spots to assemblages. Papers in Regional Science, 94(4), 753-772.

12. Chapain, C., Comunian, R. (2010). Enabling and inhibiting the creative economy: The role of the local and regional dimensions in England. Regional studies, 44(6), 717-734.

13. Gordon, I. R., McCann, P. (2000). Industrial clusters: complexes, agglomeration and/or social networks? Urban studies, 37(3), 513-532.

14. Tafel-Viia, K., Terk, E., Lassur, S., Viia, A. (2015). Creative industries in the capital cities of the Baltic States: Are there innovations in urban policy? Moravian Geographical Reports, 23(4), 47-58.

15. O'Connor, J. (2009). Creative industries: a new direction? International journal of cultural policy, 15(4), 387-402.

16. Florida, R. (2005). Cities and the creative class. Routledge.

17. Rune, T.N.L., Volante, Q.N.B. (2010). Creative Economy Report 2010.

18. Kloudová, J., Chwaszcz, O. (2013). The evaluation of creativity effects on the regional development in the Czech Republic. International Journal of Mathematical Models and Methods in Applied Sciences.

19. Vinodrai, T. (2015). Constructing the creative economy: Design, intermediaries and institutions in Toronto and Copenhagen. Regional Studies, 49(3), 418-432.

20. McGranahan, D.A., Wojan, T.R., Lambert, D.M. (2010). The rural growth trifecta: outdoor amenities, creative class and entrepreneurial context. Journal of Economic Geography, 11(3), 529-557.

21. Evans, G. (2009). Creative cities, creative spaces and urban policy. Urban studies, 46(5-6), 1003-1040.

22. Grodach, C. (2013). Cultural economy planning in creative cities: Discourse and practice. International Journal of Urban and Regional Research, 37(5), 1747-1765.

23. Van Heerden, S., Bontje, M. (2014). What about culture for the ordinary workforce? A study on the locational preferences of the creative class in Prenzlauer Berg, Berlin. Journal of Urban Affairs, 36(3), 465-481.

24. Bereitschaft, B., Cammack, R. (2015). Neighborhood diversity and the creative class in Chicago. Applied Geography, 63, 166-183.

25. Landry, C. (2012). The creative city: A toolkit for urban innovators. Routledge.

26. Kind, S., Zu Kocker, G. (2012). Developing Successful Creative and Cultural Clusters, Berlin.

27. Krätke, S. (2010). 'Creative cities' and the rise of the dealer class: A critique of Richard Florida's approach to urban theory. International Journal of Urban and Regional Research, 34(4), 835-853.

28. Alberti, F.G., Giusti, J.D. (2012). Cultural heritage, tourism and regional competitiveness: The Motor Valley cluster. City, culture and society, 3(4), 261-273.

29. Malecki, E.J. (2007). Cities and regions competing in the global economy: knowledge and local development policies. Environment and Planning C: Government and policy, 25(5), 638-654.

30. Sýkora, L., Bouzarovski, S. (2012). Multiple transformations: Conceptualising the post-communist urban transition. Urban Studies, 49(1), 43-60.

31. Špačková, P., Pospíšilová, L., Ouředníček, M. (2016). The long-term development of socio-spatial differentiation in socialist and post-socialist Prague. Sociologický časopis/Czech Sociological Review, 52(6), 821-860. 
32. Blažek, J., Netrdová, P. (2009). Can development axes be identified by socio-economic variables. The case of czechia. Geografie, 114, 245-262.

33. Ouředníček, M., Nemeškal, J., Špačková, P., Hampl, M., Novák, J. (2018). A synthetic approach to the delimitation of the Prague Metropolitan Area. Journal of Maps, 14(1), 26-33.

34. Grekousis, G. (2018). Further Widening or Bridging the Gap? A Cross-Regional Study of Unemployment across the EU Amid Economic Crisis. Sustainability, 10(6), 1702.

35. Fan, Y., Zhu, X., She, B., Guo, W., Guo, T. (2018). Network-constrained spatio-temporal clustering analysis of traffic collisions in Jianghan District of Wuhan, China. PLoS one, 13(4), e0195093.

36. Koschinsky, J. The Executive Director of the Center for Spatial Data Science at the University of Chicago. Interpretting differential Moran's I and Local Moran's I.

Надійшла до редколегії 01.11.2018 р.

\section{Про авторів:}

Павел Беднар - PhD, завідувач кафедри регіонального розвитку, управління державним сектором і права, Університет Томаша Баті у Зліні, Чеська Республіка, bednar@utb.cz, https://orcid.org/0000-0003-1250-5762

Лукаш Данко - PhD, доцент кафедри регіонального розвитку, управління державним сектором і права, Університет Томаша Баті у Зліні, Чеська Республіка, danko@ utb.cz, https://orcid.org/0000-0001-7404-8857

\section{Об авторах:}

Павел Беднар - $\mathrm{PhD}$, заведующий кафедрой регионального развития, управления государственным сектором и права, Университет Томаша Бати в Злине, Чешская Республика, bednar@utb.cz, https://orcid.org/0000-0003-1250-5762

Лукаш Данко - PhD, доцент кафедры регионального развития, управления государственным сектором и права, Университет Томаша Бати в Злине, Чешская Республика, danko@utb.cz, https://orcid.org/0000-0001-7404-8857 